\title{
STANDARDISASI, KASTOMASI DAN IMPLEMENTASI DALAM STRATEGI PEMASARAN GLOBAL
}

\author{
Oleh : \\ Purwanto
}

\begin{abstract}
Abstrak
Saat ini dunia rasanya semakin menyusut dengan pesat. Perasaan susutnya dunia ini disebabkan adanya, percepatan arus komunikasi, arus informasi, transportasi, dan distribusi, semuanya ini didorong oleh percepatan perkembangan ilmu pengetahuan dan teknologi.

Analisis strategi standardisasi, kastomasi dan pluralisasi konsumsi ditelaah secara literer dan juga dipadukan dengan sejumlah kasus-kasus bisnis yang mempunyai relevansi. Dua dari tiga konsep tersebut yaitu strategi kastomasi dan strategi pluralisasi konsumsi sensitif dengan perubahan lingkungannya.

Bidang bisnis atau bidang ekonomi pada umumnya sangat sensitif terhadap perubahan. Maka dari itu pelaku-pelaku bisnis dalam menghadapi liberalisasi ekonomi, sudah tidak populer lagi jikalau ruang gerak mereka masih berputar dikawasan sendiri, sementara pesaingnya sudah semakin agresip memasuki kawasan global. Kondisi ini tercipta karena saat ini sudah tidak ada lagi penghambat birokrasi dan penghalang-penghalang lain untuk mencegah keluar masuk pelaku-pelaku bisnis di luar kawasan. Manajemen perusahaan global sudah tidak tertarik lagi menggarap bisnis diwilayah. Alasannya untuk mencapai tingkat efisien maksimum dengan kisaran menekan total biaya operasi dan produksi, serta harga kompetitif.
\end{abstract}

\section{Pendahuluan}

Proses globalisasi akan semakin cepat dengan adanya perjanjian internasional untuk melakukan liberalisisi perdagangan internasional seperti GATT \& GATS tahun 1994. Kran globalisasi segera akan dibuka secara total tahun 2020 mendatang.

Kondisi ini sungguh tidak dapat ditawar dan dihindarkan lagi oleh negara manapun. Ironis memang, kelak negara kaya semakin kaya dan tidak menutup kemungkinan negara miskin akan semakin menderita dan mereka ini akan menjadi penonton 
pemain-pemain, badut-badut peran utama/pelaku utama globalisasi. Menghadapi pelaksanaan liberalisasi perdangan bebas banyak negaranegara telah menyiapkan diri guna memperkokoh perekonomiannya dengan membentuk aliansi-aliansi atau zona perdagangan bebas regional seperti: AFTA, NAFTA, dan APEC, tidak kalah perannya negara majupun tidak mau ketinggalan juga membentuk aliansi seperti MEE (Masyarakat Ekonomi Eropa) yang beranggotakan: Belgia, Eropa Barat, Belanda, Denmark, Luxemburg, Perancis, Portugis, dan Spanyol dengannya di Brussel Belgia. MEE membawa dampak besar terhadap perekonomian dunia, karena mereka telah menerapkan free trade dalam pasar areanya yang dimulai sejak tahun 1992 kemudian diikuti berlakunya uang tunggal Euro Dollar dan ini sungguh semakin memperkokoh posisi mereka di arena perdagangan bebas.
Sejalan dengan liberalisasi ini "konsep dan praktik manajemen modern menempati peran yang sangat penting dan strategis. Para manajer masa kini dan para manajer masa depan harus memiliki prespektif global di dalam banyak bidang, umumnya dalam bidang pemasaran dan strategi bisnis" (Sabinen Ada, 1994: 1) Sehubungan dengan hal itu maka prespektif paling penting yang dapat dikembangkan adalah kemampuan berfikir secara global. Berfikir secara global dapat diartikan sebagai kemampuan untuk memahami pemasaran internasional dan mampu melakukan perubahan-perubahan radikal, memiliki motivasi tinggi, kreatifitas dan inivatif yang ber-hubungan dengan: 1) Dimensi sumber-sumber permintaan, 2) Dimensi sumbersumber supply, dan 3) Dimensi metode pemasaran yang efektif, efisien dan agresif. llustrasi dimensi yang dimaksud adalah:

\section{Fungsi Dimensi Pemikiran Global}

\begin{tabular}{|c|l|l|}
\hline No & \multicolumn{1}{|c|}{ DIMENSI } & \multicolumn{1}{|c|}{ HASIL PRAKTIS } \\
\hline 1 & Memahami permintaan & $\begin{array}{l}\text { Bagaimana memasarkan kepada } \\
\text { pembeli seluruh dunia }\end{array}$ \\
\hline 2 & $\begin{array}{l}\text { Memahami sumber-sumber } \\
\text { supai/inventory }\end{array}$ & $\begin{array}{l}\text { Bagaimana memperoleh sumber- } \\
\text { sumber ekonomi secara efisien }\end{array}$ \\
\hline 3 & $\begin{array}{l}\text { Memahami metode } \\
\text { manajemen dan pemasaran }\end{array}$ & $\begin{array}{l}\text { Bagaimana membuat dan } \\
\text { memasarkan dengan cara yang lebih } \\
\text { tepat dan efektif }\end{array}$ \\
\hline
\end{tabular}

(Sabinen Ada, 1994:2)

Mengapa suatu negara cukup makmur sedangkan yang lain tidak?
Beberapa orang mungkin menjawabnya secara naif yaitu karena mereka 
memiliki sumberdaya alam yang berlimpah. Tetapi Switzeland, Jepang, dan Singapore tidak memiliki sumberdaya alam, mineral, dan bahkan tanahnya sempit dan terbatas apa lagi Jepang sebagian besar pegunungan. Sebaliknya Indonesia, Rusia, Nigeria, Brasil, memiliki sumberdaya alam melimpah tetapi toch miskin dan standar hidupnya/pendapatan perkapitanya sangat rendah.

Jawaban realistis terhadap pertanyaan diatas terletak pada "tata nilai/budaya dari masing-masing negara". Kuncinya adalah bagaimana rakyat/sumber daya manusianya dalam negara tersebut mau merespon perubahan-perubahan atau memberdayakan diri berfikir mengenai pasar global dan metode-metode manajemen yang berwawasan pasar global. Kultur/budaya orang Jepang, Selandia baru, merupakan nilai/aset negara yang sangat potensial. Mereka (orang-orang Jepang) adalah tipe manusia gila kerja/work-alkhoholic. Kemudian Singapore berperan sebagai "globalized economy", dengan ciri: negara sedikit kemiskinan, sedikit kejahatan, budaya bersih, teratur dan bahkan Singapore tertinggi dalam penguasaan komputer. Berbagai aspek kehidupan individu dan bisnis, orang-orang Singapore ditengarai memiliki perspektif global. Hal ini ditandai "pada tahun 90-an Shipping System di pelabuhan Singapore rata per hari lebih dari $300 \mathrm{ka}$ pal yang bongkar muat, semuanya itu dikerjakan dengan sistematik, cepat, akurat, dengan waktu pelayanan tidak lebih dari 45 menit dan sistem ini tercanggih di dunia". (Sabinen Ada, 1994:2)

Beberapa indikasi yang diidentifikasikan sebagai faktor pengayaan untuk menangkap peluang global: Alvin Toffler, dalam bukunya yang berjudul "Future Shock" dalam topik Tingkat Perubahan yang Cepat di Abad 21, meramalkan:

1. Bahwa di dalam diri kita pada abad 21 semua aspek kehidupan manusia termasuk perilaku keorganisasian akan mengalami tingkat perubahan yang sangat cepat. Ramalan atau prediksi Toffler telah menjadi kenyataan, runtuhnya tangan-tangan besi seperti Uni Soviet, menyatunya kembali Jerman barat dan Jerman Timur. Sistem perekonomian tertutup dan anti perubahan yang dipertahankan puluhan tahun itu sudah tidak sesuai lagi dengan situasi dan tuntutan jaman, pengendalian ekonomi sebaiknya diserahkan pada mekanisme pasar. Sistem ekonomi yang menerapkan sistem pasar bebas berpeluang munculnya tingkat persaingan tinggi. Sisi positif persaingan akan mendorong produsen untuk bekerja lebih efisien sehingga mampu menekan/menurunkan harga le- 
bih rendah dibandingkan dengan pesaing-pesaingnya Penekanan harga kompetitif (rendah) akan menjadi alternatif pilihan pasar (konsumen), daya beli masyarakat meningkat dan pada gilirannya jika keadaan seperti ini terjadi disetiap negara maka kesejahteraan, kemakmuran konsumen (masyarakat) meningkat. Sisi negatip memang tidak dapat dihindarkan, karena pelaku-pelaku bisnis cenderung mengabaikan kelompok yang lemah daya bersaingnya dan akibatnya mereka keluar dari arena persaingan. Kebijakkan efisiensi menjadi isu utama dan akan berimplikasi pada pengendalian biaya dan sasaran yang paling strategis adalah peningkatan padat teknologi dan pemangkasan penggunaan tenaga kerja manusia. Kebijakan ini akan mempengaruhi hubungan industrial/ketenagakerjaan. Seperti pemutusan hubunga kerja (PHK) dan hampir dipastikan timbul pengangguran baru, memang itulah korban pembaharuan. Pada tahun 30an Amerika Serikat sudah melakukan beberapa pembaharuan dalam mekanisme pasar yang bersifat alamiah. Pembaharuan itu dilakukan oleh Presiden Franklin D Roosevelt pada tahun 1933 melalui pengaturan-pengaturan oleh pemerintah atas sistem kapitalisme pasar. Perubahan kebijakan Presiden Franklin D Roosevelt agaknya lebih rasional, sebab pemerintah memperhatikan masalah pengelolaan hubungan industrial (ketenaga kerjaan-pengusaha) dan pengangguran, disamping isu pokok tentang mekanisme harga sepenuhnya diserahkan pada pasar.

2. Isu Persaingan Yang Semakin Meningkat

Pada tahun 1990-an merupakan dekade yang paling kompetitif dari abad ini. Semakin banyak para pesaing yang memasuki domestik secara global. Para manajer strategis harus mampu merumuskan taktik dan strategi untuk bersaing dalam pasar yang menawarkan sedikit harapan pertumbuhan secara keseluruhan dan dengan demikian market share (pangsa pasar) menjadi semakin kritis. Bisnis modern adalah suatu Market Share Game dengan ciri: kreatifitas, inovatif dalam produk, proses, style, pengepakan, pelabelan, strategi pemasaran, dan manajemen. Bahkan manajemen merupakan 
elemen penting dalam proses pembahruan.

3. Hypercompetition Yang Semakin Menggigit

Hypercompetition merupakan konsep strategi bersaing berkelanjutan. Hampir tidak ada satu organisasi/ perusahaan yang tidak membangun suatu keunggulan bersaing yang kontinyu. Munculnya realitas persaingan dalam lingkungan yang dinamis dengan intensitas yang tinggi untuk mencapai puncak kemenangan bersaing digambarkan dengan jelas dalam hypercompetition.D Aveny menyatakan "Hypercompetition is an environment of intense change, in which flexible, aggressive, innovative competitor move into markets easily and rapidly, eroding the adventages of the large andestablished players". (1994:ix). Revolusi teknologi, globalisasi, metode bisnis baru, teknologi pemrosesan informasi dan komunikasi baru yang radikal, peralatan/kapasitas manufactur yang fleksibel dan tenaga kerja dengan upah yang sangat layak, semuanya bersatu turut membangun persaingan pasar di seluruh dunia. D Aveni juga menguatkan adanya hukumhukum baru untuk bersaing tingkat tinggi melalui konsep
The New Rules Hypercompetition with New 7S's, sebagai berikut:

1) Superior Stakeholder Satisfaction

2) Strategic Soothsaying

3) Positioning for Speed

4) Positioning fo Surprise

5) Shifting the rules of competition

6) Signaling strategic intent

7) Simultaneous and Sequential strategic chrusts (199431)

4. Perubahan teknologi

Kebanyakan perusahaan dalam beberapa cara berdasarkan tek-nologi untuk memperoleh keunggulan bersaing yang perlu untuk tetap bertahan hidup atau sukses, apakah mengenai produk atau teknologi proses. Usaha untuk mendukung pertumbuhan tersebut maka serta merta harus diikuti perubahan teknologinya secara agresif di hampir semua sektor industri. Akan tetapi jika terjadi penghentian dari keadaan pengembangan teknologi (stagnan), akan memberikan ancaman utama bagi perusahaan.

5. Knowledge Society (Transisi dari masyarakat industri ke masyarakat pengetahuan) Pengetahuan telah menjadi kekuatan yang strategis. Pe- 
ngetahuan dapat membangun keunggulan strategis. Pengetahuan merupakan keunggulan yang berkelanjutan dan berjangka panjang. Contohnya perusahaan dapat bersaing berdasarkan pengetahuan mereka mengenai suatu proses baru atau kemampuan mereka menciptakan produk dan jasa baru. Pengetahuan mengenai para pelanggan juga akan memberikan keunggulan bersaing. Oleh karena itu menguasai pengetahuan dan me-manejemen pengetahuan dapat mengarahkan dan memberikan inovasi berkelanjutan.

\section{Standardisasi versus Kastomasi}

\section{A. Standardisasi}

Standardisasi disebut juga "globalisasi" dan "uniformitas", standardisasi berusaha memperoleh keuntungan bersaing melalui produksi yang efisien, dan berusaha menyatakan kebutuhan pelanggan dengan produk perusahaan. (Sabinen Ada. 1994:5)

Berbicara masalah standardisasi dan kastomasi memang agak bias. Standardisasi tidak generic, standardisasi bersifat dinamis. Standardisasi potensial untuk menciptakan motif-motif keinginan konsumen yang bersifat fondamental. Karena itu standardisasi dibuat agar memiliki daya tarik (appeal) dunia, sebab konsep standardisasi pada dasarnya memiliki trend yang sama di seluruh dunia. Banyak contoh mengenai produk terstandard dalam pasar dunia, misalnya: Gillette, Coca-Cola, Pepsi, hamberger, KFC, BMW, Mercedez, Sony, dan lain-lain.

Para pendukung standardisasi menyatakan bahwa dunia bergerak ke arah "homogenitas" (persamaan), yang lebih besar. (Sabinen Ada. 1994:5). Sedangkan Levitt (1983) dalam karyanya yang berjudul "The Globalization of Market" dia merupakan salah satu pendukung yang paling vokal mengenai standardisasi menuntut perlunya globalisasi pasar. Levitt memandang adanya kecenderungan yang jelas menuju "homogenisasi" yang lebih besar dari pasar dunia. la berpendapat bahwa para konsumen dunia menjadi semakin menempatakn "kesamaan peluang" untuk produk yang distandardisasi. (Sabinen Ada)

Terdapat dua manfaat standardisasi, yaitu:

1. Biaya rendah, hal ini terjadi karena adaya penghematan yang diperoleh dari skala ekonomis. Skala ekonomis ini timbul dari konsekuensi logis adanya produk masal.

2. Konsistensi. Strategis, standardisasi juga menuju prinsip konsistensi dalam strategi pemasaran perusahaan yang menjual produk terstandard di seluruh penjuru 
dunia. Penghematan terjadi dari biaya promosi yang dapat diberlakukan ke seluruh pasar sasaran.

B. Standardisasi dan Bauran Pemasaran

Standardisasi juga dapat dapat ditemukan atau diperoleh dari empat komponen bauran pemasaran, yaitu:

a. Produk

Produk yang tidak memper-oleh reaksi negatif terhadap kultur/ budaya negara tertentu biasanya akan sukses melalui program stan-dardisasi.

b. Harga

Harga yang distandardisasi nampaknya tidak banyak mengalami masalah Hambatan terjadi pada sejumlah negara yang tingkat pendapatannya rendah sehingga dimungkinkan daya beli masyarakatnya juga rendah. Tetapi bagi negara makmur, harga hampir tidak pernah menjadi masalah.

c. Place

Pasar erat hubungannya de-ngan distribusi. Distribusi juga telah dicapai pada sustu tingkat standardisasi tinggi. Negara-negara Eropa pada umumnya para pemasar menggunakan sebuah distrbusi yang sama untuk produk-produk mereka. Akan tetapi untuk negara-negara kurang berkembang standardisasi kurang diperhati- kan/kurang disukai dan tidak menjadi daya tarik.

d. Promosi

Promosi menjadi efektif apabila pemasar dapat menciptakan jenis promosi yang bersifat universal (umum), yaitu jenis iklan yang dapat diterima di seluruh dunia.

C. Implementasi Strategis dari Standardisasi

Terdapat sedikitnya tiga implikasi strategis dari standardisasi, yaitu:

a. Berfungsi atau beroperasi sebagai pemenang.

Standardisai adalah suatu strategi dengan prinsip memanfaat-kan ide-ide baru, berproses secara kontinyu dengan keyakinan bahwa suatu produk yang baik dapat dialihkan ke kultur yang berbeda-beda. Jikalau produk tersebut merupakan kebutuhan konsumen yang fondamental dan universal.

b. subsidi silang.

Perusahaan yang sudah berani masuk ke pasar global senantiasa dihadapkan pada suatu situasi yang dilematis, sebab tidak semua negara tujuan memberikan konstribusi profit yang diharapkan. Akan tetapi sudah diyakini terdapat beberapa pasar sasaran yang lain akan memberikan profit sesuai dengan rencana. Berdasarkan kenyataan tersebut mereka mengkombinasikan de- 
ngan memberikan subsidi silang terhadap biaya keuntungan yang tidak dapat dicapai pada pasar tertentu tersebut. Strategi/dasar pemikiran mereka cukup rasional, Tidak selamanya biaya ren-dah selalu memberikan profit. Terhadap produk yang hight-cost tetapi produk tersebut mempunyai potensi besar dimasa mendatang, maka bi-aya tinggi akan tertutup oleh produk yang sama yang berada pada pasar yang berbeda. Hamel dan Prahalad (1985) berpendapat, "bahwa biaya rendah saja tidak akan memberikan kesuksesan pasar dan daya saing. Mereka (pemasar) percaya bahwa standardisasi telah berfokus dengan tujuan tidak hanya pada biaya ren-dah, tujuan lain standardisasi adalah melakukan subsidi silang. Dimana perusahaan dapat menemukan atau mengurangi kerugian persaingan dalam pasar lokal dengan bersaing dengan pa- sar global". (Sabinen Ada :1994: 10)

3. Nilai produk versus pilihan produk

Pada dasarnya standardisasi yang memberikan kepada konsumen harga yang kompetitif terhadap nilai produk yang berkualitas sudah cukup memudahkan proses pembelian, dari pada hanya disediakan pilihan produk yang bervariasi. Hal ini ditegaskan oleh Levitt yang mengatakan bahwa "Para konsumen akan memilih harga yang lebih rendah dan kualitas yang paling tinggi dari pada produk yang dikastomasi (diadaptasi), jika mereka diberi pilihan". (Sabinen Ada). Kalimat terakhir inilah yang sering membawa perdebatan antara Departemen Produksi dengan Departemen Pemasaran. Sebab Departemen Pemasaran sangat dekat dengan para pelanggan sehingga mereka faham benar dengan apa yang diingikan oleh pelanggan. Berikut ini ilustrasi model produk terstandar 


\section{ILUSTRASI I \\ MODEL STANDARISASI}

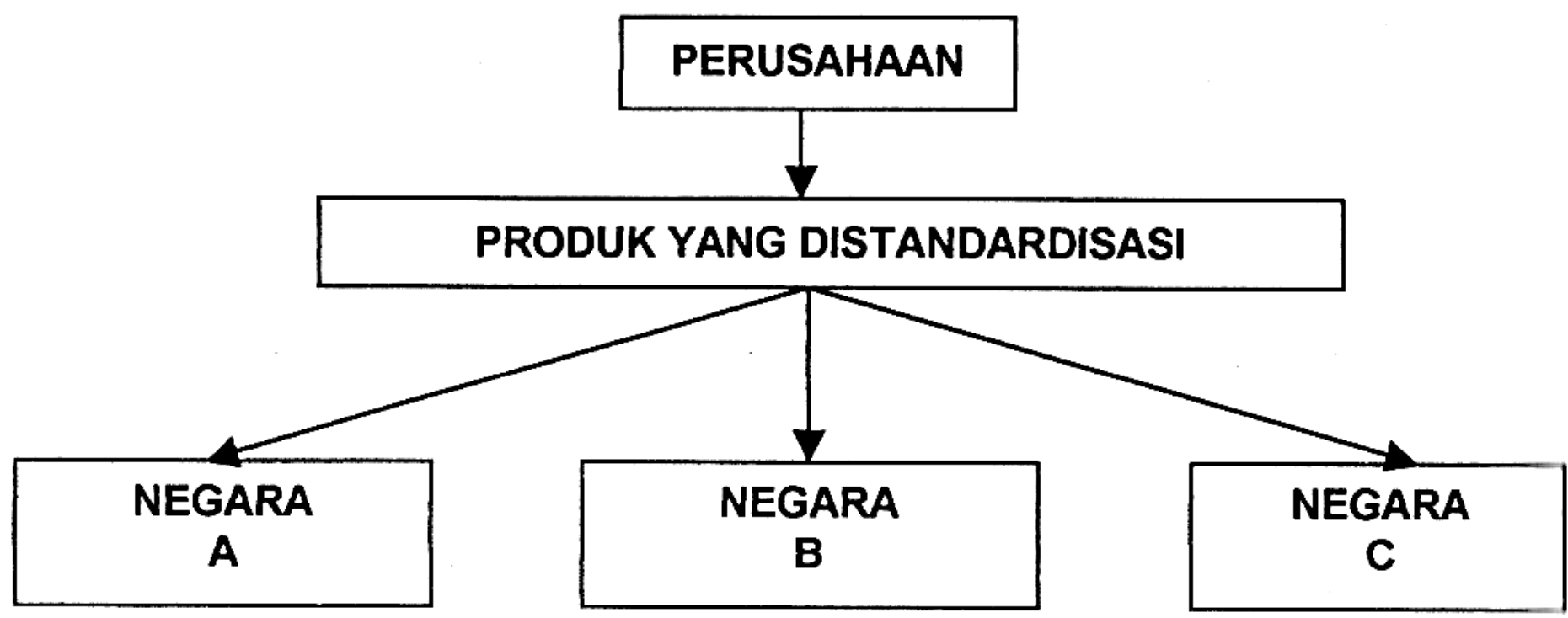

Kastomasi (Castomization)

1. Pengertian kastomasi

Kastomasi biasanya disebut juga "adaptasi" atau "localized marketing". "Kastomasi erat hubungannya dengan konsep pemasaran, sedangkan standardisasi lebih menekankan pada kebijakan produk. Kastomasi mencakup anggapan bahwa produk harus disesuaikan dengan pemenuhan kebutuhan individual pelanggan dari negara yang berbeda-beda. Kastomasi lebih erat dengan deferensiasi dan segmentasi daripada penurunan biaya dan pendukung kastomasi lebih banyak berasal dari praktisi pemasaran". (Sabinen Ada : 10)

Ironis memang kalau kita berbicara masalah standardisasi dan kastomasi dalam satu konteks ada satu makna yang berseberangan.
Pendukung standardisasi beranggapan bahwa pelanggan diseluruh dunia dengan kultur /budaya, motif, dan keinginnya yang beragam disamaratakan, dalam arti tidak diakomodasi secara adil. Konsep ini mempunyai kepekaan yang tinggi manakala kehadiran produk dirasakan mempunyai dampak negatif pada kultur/budaya pelanggan yang secara historik dijunjung tinggi. Disamping itu kenapa standardisasi menjadi fokus Departemen Produksi? Alasanya cukup masuk akal, sebab standardisasi mempunyai implikasi tinggi terhadap penurunan biaya, meningkatkan produk masal, menghasilkan konstribusi profit margin, dan ujung-ujungnya adalah efisiensi dibeberapa sektor, penurunan harga, termasuk biaya pemasaran dan periklanan. Periklanan dan pemasaran ini tergolong bi- 
aya tinggi yang harus ditanggung oleh perusahaan. Namun apakah konsep ini memiliki fleksibilitas universal?

Berikut ini kritikan dari pendukung konsep Kastomasi terhadap pendukung konsep Standardisasi yang ditulis oleh Sabina Ada sebagai berikut.

a. Konsep Standardisasi mengabaikan pelanggan

Pada umumnya strategi standardisasi menomor duakan dan atau kurang mementingkan keinginan konsumen secara keseluruhan. Mereka lebih mengunggulkan efisiensi produksi. Standardisai juga mengesampingkan kebutuhan pelanggan/konsumen dengan mengunggulkan harga rendah. Sehubungan dengan hal itu muncul pertanyaan, sudah cukupkah bagi konsumen?

Sheth berkomentar, bahwa tren menuju pasar global konsumen tidak harus dibingungkan atau dikacaukan dengan tren produk global (standar). Persaingan global tidak perlu melibatkan produk global, namun yang lebih penting pemenuhan keinginan, kebutuhan dan harapan pelanggan yang teradaptasi (Castomized) lebih diutamakan oleh manajer.

b. Standardisasi Anti Segmentasi

Standardisasi dalam pasar global bertentangan dengan segmentasi pasar pada umumnya. Perlu diingat kebanyakan pasar secara alami terbagi dalam segmen-segmen yang lebih kecil, dan setiap segmen harus diberi perlakuan yang adil. Sedangkan standardisai berasumsi bahwa banyak segmen dapat dilayani dengan satu produk tunggal. Tetapi konsep kastomasi berasumsi mereka harus melayani secara adil dengan strategi melakukan kastomasi (adaptasi) vertikal keatas dan kebawah, termasuk teknik promosinya.

c. Standardisasi Menghindar Desentralisasi

Kebijakan standardisasi bersifat kaku, semua pasar dilayani secara global dan tidak mengenal pendekatan lokal (local approach). Keadaan ini merupakan kelemahan yang bersifat fatal. Sedangkan kastomasi (adaptasi) menggunakan flexibility approach, kecepatan pengambilan keputusan sangat urgen dengan selera lokal.

d. Penghematan Biaya yang Tidak Nyata

Slogan standardisasi penetrasi biaya rendah dengan program efisiensi tinggi. Suatu Studi yang dilakukan Soreson dan Weichman (1975) dengan subyek penelitian 27 Corporasi Multinational yang menjual produk terstandar ke pasar Eropa hanya ada satu korporasi yang dapat membuktikan penghematan biaya secara nyata. Sedangkan yang lain ternyata menutup biaya dengan subsidi silang dari segmen-segmen potensial dengan jumlah relatif sedikit. Konsep kastomasi tetap konsisten 
dengan membidik pasar melalui program fleksibilitas diberbagai pasar sasaran dengan melakukan kastomasi keatas dan atau kebawah serta diikuti dengan kastomasi promosi, dan bahkan lebih enerjik dan agresif dengan program kastomasi ganda meliputi produk dan promosi.

Keegen membedakan lima strategi adaptasi produk dan promosi untuk pasar luar negeri meliputi :

1. Strategi extension (perluasan langsung berarti pemasar menawarkan produk di pasar luar negeri tanpa melakukan perubahan (adaptasi) baik dari sisi produk maupun sisi promosi. Pertimbangan umum yang harus diperhatikan oleh manajer dalam menerapkan strategi ini adalah keyakinan bahwa produk sudah digunakan oleh konsumen dan sudah menjadi kebutuhan rutin.

2. Product adaptation (adaptasi produk) mencakup perubahan produk untuk memenuhi kondisi atau preferensi lokal/ nasional. Terkait dengan masalah ini menejemen dapat melakukan adaptasi melalui berbagai tingkat, yaitu : a) peru- bahan produk versi preferensi kota/keinginan kota, b) perubahan produk versi preferensi negara, c) perubahan produk versi preferensi regional, dan d) perubahan produk versi preferensi internasional atau dengan kata lain, adaptasi produk/perubahan produk disesuaikan dengan keinginan/ preferensi pasar sasaran.

3. Product invention (penemuan produk), mencakup penciptaan sesuatu yang baru bersifat maju (forward invention) dan penemuan mundur dengan cara merekonstruksi produk yang telah ada menjadi lebih baik dari produk sebelumnya untuk dipasarkan ke negara asing tertentu, cara ini disebut bacward invention

4. adaptasi komunikasi, perusahaan melakukan kampanye periklanan dan promosi pada setiap pasar luar negeri.

5. Adaptasi ganda, yaitu perusahaan melakukan adaptasi produk dan promosi secara bersama-sama. (lihat figure berikut ini) 


\section{Lima Strategi Produk Dan Promosi Internasional}

\begin{tabular}{|c|c|c|c|}
\hline \multirow{2}{*}{ Promosi } & \multicolumn{3}{|c|}{ PRODUK } \\
\cline { 2 - 4 } & $\begin{array}{c}\text { Tidak mengubah } \\
\text { produk }\end{array}$ & $\begin{array}{c}\text { Mengadaptasi } \\
\text { produk }\end{array}$ & $\begin{array}{c}\text { Mengembagkan } \\
\text { produk baru }\end{array}$ \\
\hline $\begin{array}{c}\text { Tidak mengubah } \\
\text { promosi }\end{array}$ & $\begin{array}{c}\text { Perluasan } \\
\text { langsung }\end{array}$ & $\begin{array}{c}\text { Adaptasi } \\
\text { produk }\end{array}$ & \\
\hline $\begin{array}{c}\text { Mengubah } \\
\text { promosi }\end{array}$ & $\begin{array}{c}\text { Adaptasi } \\
\text { komunikasi }\end{array}$ & $\begin{array}{c}\text { Adaptasi } \\
\text { ganda }\end{array}$ & Penemuan \\
& & & \\
\hline
\end{tabular}

2. Motivasi Kastomasi

e. Kastomasi Sukarola, dimana perusahaan global secara aktif memutuskan untuk monyesuaikan produknya dengan selera global. Kastomasi sukarela condorung monangkap keperbodaan nasional pasar sasran dongan prinsip tidak bertentangan dongan kultur/budaya pasar sasaran. Kastomasi sukarela ini juga diperkuat oloh Kotler (1997) me- ngatakan bahwa " dewasa ini pemasaran kastomasi telah muncul kembali dalam bentuk yang disebut "Mass Custommization" kastomasi masal dan merupakan pemasaran baru yang mungkin terbuka bagi perusahaan-perusahaan yang maju dalam teknologi pembikinan. Kastomasi masal merupakan kemampuan mempersiapkan suatu produk yang dirancang secara masal dan individual untuk memenuhi 
masing-masing keperluan pelanggan.

f. Kastomasi Order Pemerintah, Ada sejumlah negara sasaran menetapkan agar produsen memasarkan produk teradap- tasi untuk memenuhi keinginan pasar individual secara adil. Keadaan ini produsen dipaksa mengubah/mengkastomasi produknya. Berikut ini model

kastomasi

\section{ILUSTRASI II \\ MODEL KASTOMASI}

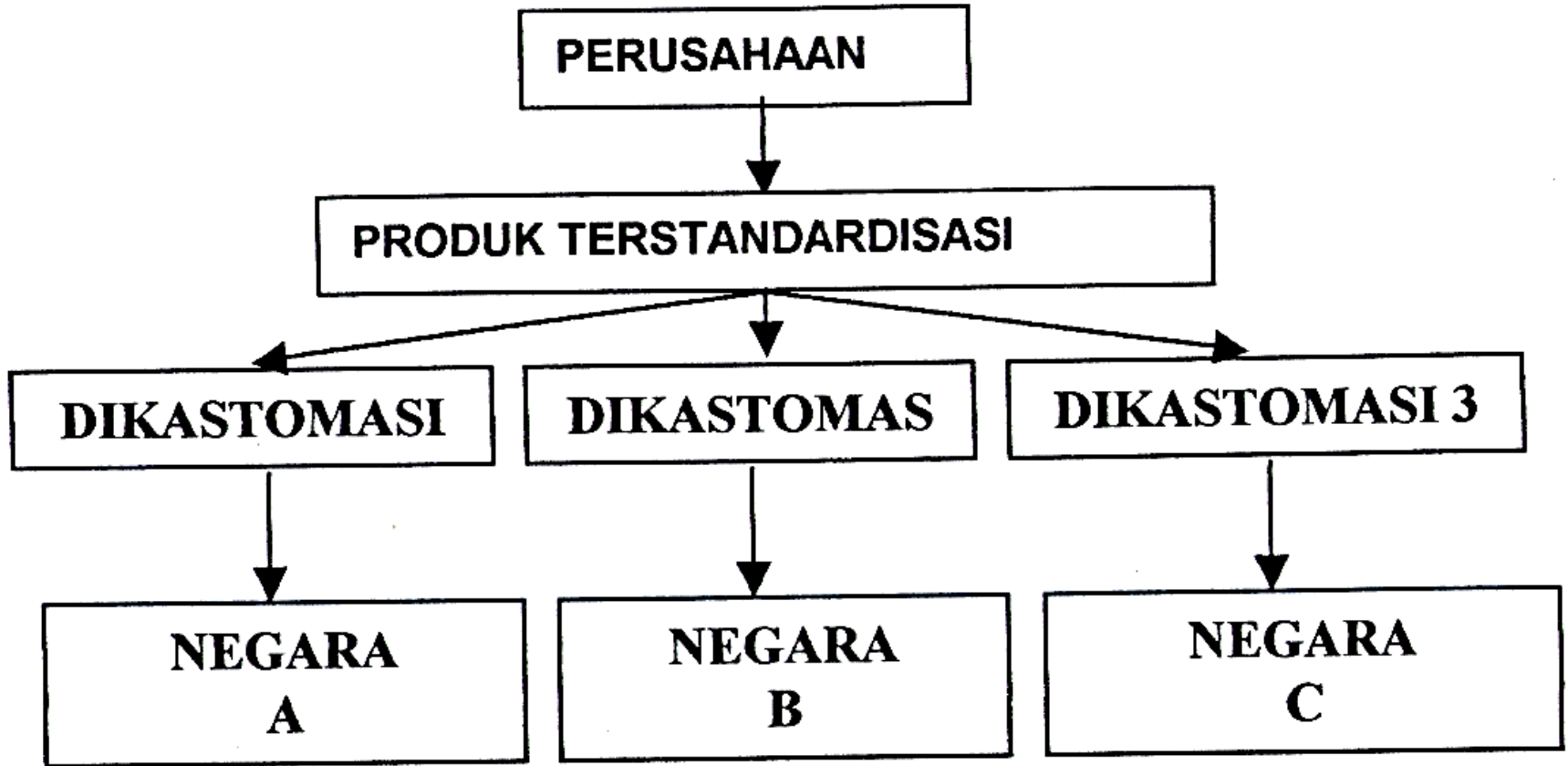

Posisi Menengah dan Pluralisme Konsumsi

Kritik terhadap dua pendekatan tersebut diatas adalah bahwa masing-masing pendekatan cenderung membicarakan secara ekstrim dan menolak atau mengabaikan "posisi menengah". Kebijakan konvensional menganggap bahwa tidak realistis bagi semua elemen dan bauran pemasaran distandardisasi.
Kita perhatikan suatu kasus produk yang dijual diseluruh dunia dengan bentuk yang sama dan hanya terdapat perbedaan kecil seperti warna, kemasan dan lain-lain. Apakah produk tersebut distandardiasai atau dikastomasi?. Gagaimana mengenai suatu produk yang sama dengan segala pertimbangan khusus (misalnya masalah kultur/budaya) sehingga muncul sistem/bentuk periklanan yang berbeda-beda di setiap 
negara sasaran?. Apakah itu termasuk standardisasi ataukah kastomasi?

Yang pasti itu justru menambah kebingungan lain yang akan menambah masalah tersebut. Kemudian ada suatu perusahaan yang menjual produk yang sama dalam 10 negara yang berbeda secara jelas perusahaan tersebut menjual produk yang distandardisasi. Akan tetapi bagaimana halnya jikalau ada suatu perusahaan menjual 5 produk yang berbeda-beda masing-masing dijual secara eksklusif dalam satu dari 10 pasar, untuk keseluruhan dari pasar yang berbeda-beda?. Apakah perusahaan tersebut juga terlibat dalam standardisasi, atau molakukan kastomasi produk-produknya untuk memenuhi kebutuhan khusus? Biasanya standardisasi dan kastomasi secara konseptual jelas, tetapi secara praktis membingungkan.

Terdapat persotujuan/negosiasi umum bahwa standardisasi murni adalah tidak dianjurkan atau bahkan tidak mungkin. Jadi standardisasi tidak mungkin dicapai bentuknya yang paling murni untuk kebanyakan perusahaan dan produknya. Standardisasi dan kastomasi masing -masing terlalu ekstrim. Posisi menengah dan fleksibilitas adalah kuncinya. Konsep pemasaran selera konsumen, pertimbangan strategis, pertimbangan kultur/budaya dan hanya yang bersifat praktis mereka berjalan dan bekerja berlawanan dengan strategi standardisasi mumi. Ada diantaranya terdapat celah/gap yang tidak tersentuh.

Levitt berusaha untuk menjelaskan debat mengenai standardisai dan kastomasi dengan suatu konsep yang disebut "PLURALISASI KONSUMSI". la tetap berpendapat dengan anggapan yang semula, bahwa ada kecenderungan yang jelas menuju "HOMOGINITAS PASARAN GLOBAL". Kemudian dalam komunikasi dan transportasi menciptakan ide-ide yang identik, preferensi yang paralel, dan pola konsumsi yang disamakan. Pasaran global sedang terjadi pemusatan, kastomasi berusaha mengadakan adaptasi. Akhirnya muncul suatu kecenderungan konsumen terobsesi oleh berbagai preferensi (orang/konsumen akan mengikuti apa yang dikatakan oleh pihak lain dan mereka dengan sadar atau tidak akan mengikuti preferen tersebut).

Bersamaan dengan itu Levitt menyadari adanya suatu kecenderungan dan perubahan pola "PLURALISASI PREFERENSI KONSUMSI" Artinya konsumen sudah tidak begitu peduli lagi adanya kesamaan yang diisyaratkan untuk dibeli dalam masing-masing negara. Banyak negara di dunia ini yang menyajikan/ menjual berbagai komuditas, khususnya tentang makanan diluar makanan khas domestik. Makanan khas negara-negara tetangganya yang disediakan sudah banyak diminati oleh 
etnis/bangsa lain. Misalnya di Indonesia banyak restoran-restoran yang menjual makanan berbagai etnis negara sahabat, misalnya masakan $\mathrm{Ci}$ na, masakan Perancis, masakan Jepang, dan lain-lain. Orang yang datang ke restoran tersebut sudah sangat hiterogen. Kontradiktifnya masakan boleh hiterogen, tetapi konsumennya bisa homogen. Levitt menegaskan bahwa para konsumen nampaknya aewasa ini menjadi bagian dari segmen preferensi yang logis. Berikut ini Model Pluralisasi Konsumsi

\section{ILUSTRASI III \\ MODEL PLURALISASI KONSUMSI}

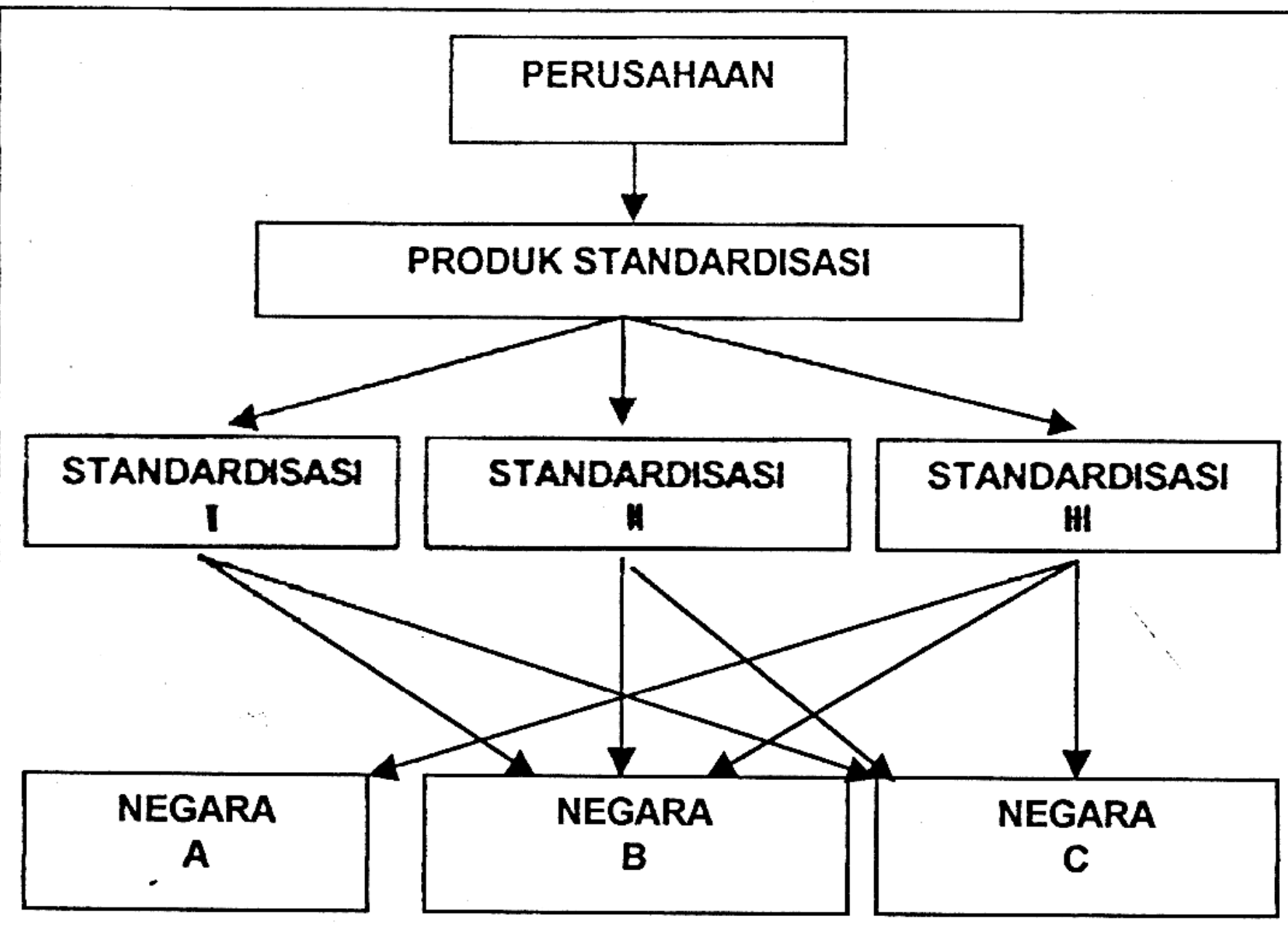

\section{Penutup}

Kritik mempertahankan suatu strategi satardisasi murni, kastomasi murni adalah tidak fisibel. Meskipun demikian peluang-peluang yang bergerak menuju kearah standardisasi maupun kastomasi nampaknya dapat membawa sukses manakala 
produk memiliki karakteristik tertentu yang bersifat fondamental. Akan tetapi jika hal itu kurang terpenuhi banyak masalah-masalah yang dijumpai pada saat pemilihan dan pelaksanaan strategi. Berikut ini suatu analisis untuk mencari kesamaankesamaan dan kekhasan masingmasing strategi untuk dipilih berbagai alternatifnya oleh manajemen dalam menentukan kebijakannya strategisnya.

\section{Mencari Kesamaan Dalam Pasar}

Manfaat standardisasi dapat dicapai dengan mentargetkan produk yang distandardisasi ke pasar global yang momiliki ciri/karakter yang sama. Persoalan penting bukan masalah dipilihnya strategi standardisasi, totapi masalah kapan strategi standardisasi ini harus laksanakan? dan sampai seberapa jauh strategi ini gunakan?, dan elemenelemen mana saja dari strategi tersebut yang dapat distandardisasi? dan sampai lovel mana strategi ini di implementasikan?. Produk dan promosi yang distandardisasikan akan sukses jika ditargotkan pada pasar global yang momilikl karakteristik yang sama. Moncari pasar yang sama dengan strategi promosi dan produk yang distandardisasi adalah serupa menggabungkan segmen-segmen dalam pasar domostik. Dalam pasar global sama fonomenanya dengan pasar domostik segmensegmen yang sama adalah paling memungkinkan mudah menanggapi perubahan secara baik dari program produk tunggal, produk teradaptasi pada pasar yang berbeda-beda. Keenturan produk tunggal, produk terdaptasi dan komunikasi promosi yang fleksibel jelas sangat dekat degan pluralisasi konsumsi. Kemudian timbul pertanyaan apakah itu yang dimaksud dengan strategi standardisasi? ...... dan apakah itu bukan ciri dari strategi kastomasi? ... lalu apa pula bedanya dengan strategi pluralisasi konsumsi? Memang keadaan pasar sangat peka terhadap perubahan, karena itu pemilihan dan penerapan salah satu strategi secara murni sungguh sulit untuk diprediksi secara akurat.

2. Mencari Kesamaan Dalam Produk

Standardisasi dapat juga ditargetkan pada produk-produk yang sama, seperti elektronik, kamar hotel, otomotif, bahan bakar, dan sebagainya, semua itu sungguh-sungguh sama krakteristiknya di seluruh dunia. Mereka melayani kebutuhan konsumen yang fondamental. Kategori produk yang lain yang memiliki ciri khas, bersifat nasional tidak cocok distandardisasi. Produk lain yang memiliki perbedaan tipis dan bahkan hampir sama dengan produk standar belum tentu bisa bersaing di pasar global jika tanpa melalui perubahan/adaptasi (kastomasi). Contohnya jasa entertainmen seperti film produk Hollywood, film ini masuk 
pasar Indonesia harus lolos sensor. Sehubungan dengan itu kastomasi merupakan alternatif pilihan.

\section{Daftar Pustaka}

Buzzel, R.D., (1973), Can You Standardize Multinational Marketing?, Managing The Multinational, A Harvard Business Review Series, pp Buzzel, et al., (1992), Global Marketing Management, New York, Addison-Wesley D'Aveni, Richard.A., (1994), Hypercompetition-Managing the Dynamics of Strategic Maneuvering, New York, Macmillan, Inc Kotler Philip, (1997), (Edisi Indonesia), Manajemen Pemasaran, Jakarta, PT Prenhallindo
Sabinen Ada, (1994), Standardisasi dan Kastomasi dalam Strategi Pemasaran Global, Jakarta, Salemba Raya

Zimmerer, et al., (1998), (edisi Indonesia), Pengantar kewirausahaan dan Manajemen

Bisnis Kecil, Jakarta, PT Prenhalindo.

\section{Biodata Penulis}

Drs. Purwanto, MM. Adalah staf pengajar pada program studi Pendidikan Administrasi Perkantoran, Fakultas IImu Sosial, Universitas Negeri Yogyakarta. 